\title{
The Implementation of Defense Development Policy with Blended Learning Technology
}

\author{
Wibisono Poespitohadi, Soesilo Zauhar, Bambang Santoso Haryono, Fadillah Amin, Zaenal \\ Fanani, Romy Hermawan
}

\begin{abstract}
The development of the Universe Defense System is aimed to produce strong deterrence both to be physically armed, to have high ability to defend the country, and to consciously arm him or herself psychologically by cultivating the values of the Pancasila ideology. The purpose of this study is to create a safe, comfortable, productive, effective, efficient, sustainable, and environmentally sound spatial structure based on trade, services and a national creative industry. This study uses qualitative methods with the theory of cooperation. The results of regional research will provide guidelines for the preparation of regional territorial arrangements, respectively, institutions guidelines, accountability, different ways of thinking, assessment so as to occur in the form of insufficiency; The conclusion obtained is that the implementation of regional governance policies relating to the unit title to protect Obvitnas in the capital city of Jakarta cannot be implemented properly. With blended learning technology that can use all existing media ranging from text, sound, images (moving images and still images) to animation, and videos, it can facilitate existing implementations
\end{abstract}

Index Terms: Blended Learning Technology, Implementation of The defani, Development Policy

\section{INTRODUCTION}

In the concept of sustainable and environmentally friendly urban development in general, there are still those who carry out regional development without careful planning in the future. As known, to create a comfortable city for people who live in the city, urban planning is an important activity that must be carefully planned. However, some regions in Indonesia have begun to pay attention to urban spatial planning for example in West Java Province which already has a Regional Spatial Plan in this case Bandung City (Sutriadi \& Wulandari, 2014) which is in accordance with the Regional Regulation of Bandung City Number: 18 of 2011 concerning City Spatial Planning of Bandung in 2011-2031 (Tarigan et al., 2016).

In terms of the relationship between the regional government and the defense function, we can see in the Republic of Indonesia Law Number 3 of 2002 (PRESIDEN

Revised Manuscript Received on September 22, 2019.

Wibisono Poespitohadi, Public Policy, Universitas Brawijaya, Malang East Java Indonesia, wibisonophim@gmail.com

Soesilo Zauhar, Public Policy, Universitas Brawijaya, Malang East Java Indonesia

Bambang Santoso Haryono, Public Policy, Universitas Brawijaya, Malang East Java Indonesia

Fadillah Amin, Public Policy, Universitas Brawijaya, Malang East Java Indonesia

Zaenal Fanani, Farm Faculty, Universitas Brawijaya, Malang Jawa Timur Indonesia

Romy Hermawan, Public Policy, Universitas Brawijaya, Malang East Java Indonesia
REPUBLIK INDONESIA, 2002) concerning National Defense, Article 20 stating:

1. The development of national defense capabilities is intended for the implementation of a national defense system as referred to law.

2. All national resources in the form of human resources, natural and artificial resources, values, technology, and funds can be utilized to improve national defense capabilities which are further regulated by Government Regulation.(Tuballa \& Abundo, 2016)

3. Development in the regions must pay attention to the development of defense capability as referred to paragraph (1) which is further regulated by Government Regulation.

In the implementation of autonomy, the regions have obligations including protecting the community, maintaining national unity, harmony and integrity, and the integrity of the Unitary Republic of Indonesia (NKRI). Based on this description, the nature of defense affairs is also the responsibility of the regional government to maintain the framework of maintaining safeguards against state sovereignty.

Furthermore, with the interrelationship between the spatial field and the field of defense area arrangement, it has been explained in the Republic of Indonesia Law number 26 of 2007, in article 17 (P. R. INDONESIA, 2007) namely further provisions concerning the procedure for preparing spatial plans relating to defense and security functions as a spatial plan subsystem territory regulated by government regulations.

In preparing for the implementation of the Universal Defense System, there are 5 things that need to be built namely those related to the political system, the economic system, the socio-cultural system, the technology system and the defense system. Defense systems are built and developed to safeguard (Hausken, 2010) and preserve the independence and sovereignty of the State and territorial integrity (NKRI). The defense system played by the Indonesian Armed Forces (TNI) is strong and professional supported by community in the universal people's defense (D. M. O. T. R. O. INDONESIA, 2015)system with high deterrence and guaranteeing the stability of national security which enables the implementation of national development.

The universal defense system is built to produce resilient power and it is a dynamic condition of the Indonesian nation which includes all aspects of integrated national life, containing resilience which covers the ability to develop national forces in facing and overcoming challenges, threats, obstacles and disturbances that come from outside and inside of the country. To guarantee

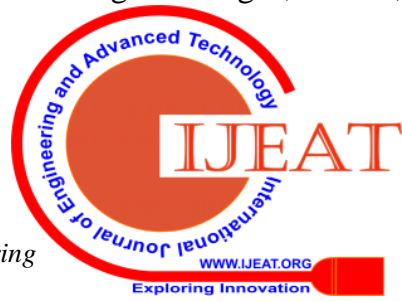


the identity, integrity of the survival of the nation and state and the struggle to achieve national goals must remain in order to realize national ideals namely to form a Unitary Republic of Indonesia (LAN, 2017) which is independent, united, sovereign, just and prosperous.

The development of the Universe Defense System was built to produce strong deterrence, not only to be physically armed with the high ability to defend the country, but also to consciously arm him or herself psychologically by cultivating the values of the Pancasila ideology(Fuad, 2014). Enhancing individual's ability with science and technology is as an implementation of the social weapons system. Then, the development of the National Defense System can be built through Geographic Aspects, Demographic Aspects and Social Conditions Aspects (Conditions of Ideology, Politics, Economics, Socio-Culture and Defense Security) (BASIAGO, 1999)

In preparing national defense in terms of geographical aspects, the Regional Government and the Kodim have the same task to organize the geographical aspects in accordance with their respective authorities. The Regional Government makes the Regional Spatial Planning of the Regional Government of Bandung City with the aim of creating a safe, comfortable, productive, effective, efficient, sustainable, and environmentally sound, spatial based on trade,(Wicaksono Sarosa, 2012) services and creative industries with a national standard. Meanwhile, the Kodim is in accordance with the Decree of the Minister of Defense No. KEP / 216 / M / III / 2012 dated March 26, 2012 (MENHAN, 2013) concerning the Defense Office Central Control Desk (DPPKP), the Kodim is currently acting as the one who assists the Adhoc Korda DPPKP officials in implementing tasks and functions. Ministry of Defense is aimed to prepare a defense area that can be used to develop all the potential for defense as a regional power when the country is in danger or urgent situation of war. This difference in conceptions and objectives can lead to differences between the spatial plans prepared by the Regional Government and the TNI's defense plan.

Blended learning technology is a part of information technology (River, Currie, Crawford, Betihavas, \& Randall, 2016)that can combine all existing media to produce information, ranging from text, sound, still images, moving images, videos and animation. With the support of information technology, blended learning technology is expected to facilitate the data processing that will be carried out to produce information in accordance with the wishes.

The enthusiasm of the two agencies in principle is the success of development, prosperity and protecting the community. Policy and development are basically two interrelated concepts as instruments of government (state) in carrying out two main functions, namely the function of regulation (regulation) and function of services (services) in the context of public welfare (Lindgren, Madsen, Hofmann, \& Melin, 2019). As a process of realizing community welfare, development is the context in which policy operates. Meanwhile, policies are pointed to the development of framework which provides guidance or a foundation for processes, implementation and development goals into various programs and projects. So, the policy function in development is to provide a formula regarding the choice of actions and priorities to achieve development goals

The purpose of this study is to create a spatial structure that is safe, comfortable, productive, effective, efficient, sustainable, and environmentally sound, based on trade, services, and the national creative industry by utilizing blended learning technology. To describe and analyze the process of synergy from the implementation of spatial policies, it is compiled by the Bandung City Government with plans for land defense areas compiled by the 016 / BS regime.

\section{LITERATURE REVIEW}

Policy is an instrument of government, not only in the sense of government concerning (Gregory, 2019) state apparatus but also governance that touches management of public resources. Then, public policy comes with a specific purpose that is to regulate life together and to achieve the agreed goals (Belletti, Marescotti, \& Touzard, 2017) (mission and vision). Public policy is a way to achieve the shared goals that are aspired. Public policy is understood as a policy made by government agencies and political actors aimed at resolving public problems.

Public policies generally contain (Merad \& Trump, 2018) the notion of: "whatever government chooses to do or not to do", which means "whatever the government chooses to do or not do". Another opinion is "public policy is what the government chooses to do or not do (public policy choose to do or not to) ". The definition of public policy is also: "a relatively stable, purposive course of action". The definition of public policy is given that broadly public policy can be defined as the relationship of a government unit with its environment'(Kivimaa, Hildén, Huitema, Jordan, \& Newig, 2017). The other opinion is "a sanctioned course for a particular problem", (a sanctioned action that leads to a certain interrelated goal that affects most people).

The implementation of policies to understand what actually happens after a program is valid or formulated is the focus of policy implementation attention, namely events and activities that arise after the ratification of guidelines for public policy that includes both efforts to administer it and to cause consequences or real impact on the community or events.

The policy is an effort to actualize the alternatives chosen to solve the problem (Dutta, 2018). the implementation of policy as a process of interaction between determinants of goals and actions to achieve goals. This process is very important and crucial since the effectiveness of policies is also determined at this stage.

Policy implementation in a broad sense refers to a stage of the policy process immediately after the enactment of the law (Hasan, 2019). Implementation means implementing laws where various actors, organizations, procedures and techniques work together to carry out policies in an effort to achieve policy goals or programs.. Implementation is the next cycle of policy formulation as a process so that the policy can achieve its objectives. Therefore, implementation is not only interpreted as a government action but is as an action related to political, economic, social and cultural aspects including the actors of policy implementation. These aspects either directly or indirectly 
have an influence on the success of policy implementation.

The new general policy is not accompanied by an adequate budget. To obtain a budget for lobbying, identify budgetary sources that support implementation and negotiate to get relocation of resources. Implementation of policy in principle is a way for a policy to achieve its objectives. If we look at the presentation of the success of a policy, the policy plan contributes $20 \%$ to success, $60 \%$ implementation and the remaining $20 \%$ how we control policy.

Furthermore, the concept of synergy has similarities with the concept of collaboration that is an individual process and an independent organization that combines human resources and material resources to be able to achieve their goals rather than achieving goals individually. '

The digital technology policy is the role of government in promoting technological innovation in public service delivery. Government needs to be first digitized (Chatfield \& Reddick, 2019) (e.g, one stop e-government portal and social media platform) and expand to data communication (e.g, on demand capability through big data and analytics) before the government can handle real-time sensor data continuously generated by the ubiquitous IoT objects and devices. It would be difficult for governments to move directly into IoT innovation without having a firm digital technology policy.

The process of developing national and regional space programs begins with the drafting of Space Policy, which are generally states, objectives, principles and guidelines for such programs. Public policies problems are generally categorized as wicked problems (Gharehgozli, Mileski, Adams, \& von Zharen, 2017). They are difficult to be clearly defined since different stakeholders have a problem that is involved in the coordination of action, objectives, principles and guidelines for such programs.

Technology is involved in systematically attempting to look into longer-term future of science, technology, economics and society with the aim of strategic research and the influencing of generic technologies likely to result the greatest economic and social benefits.

\section{METHODOLOGY / MATERIALS}

This study employs a qualitative approach that is an approach or method that is appropriate and in accordance with the symptoms of this study. Determining methods is closely related to determining how the data is obtained, and how to analyze data. Research on spatial policy in structuring defense areas in the city of Bandung used a qualitative descriptive research method. The approach used in this study is qualitative, and the nature of the research is descriptive. This study employs a qualitative approach considering the nature of the problem under study. To uncover a problem relating to seeing a particular phenomenon, it is more suitable to use qualitative methods.

This study will analyze the implementation of spatial policies in structuring defense areas in the city of Bandung which will be reviewed in terms of inhibiting factors and their driving factors, then also how the impact of the implementation of current policies in the field of land defense arrangement. Qualitative approach is a method based on post positivism philosophy used to examine the condition of natural objects where the researcher is a key instrument. In this study, the sample was chosen by using purposive sampling. To collect data, the technique used was triangulation (combined), data analysis is inductive and the results more emphasis on the meaning of generalization.

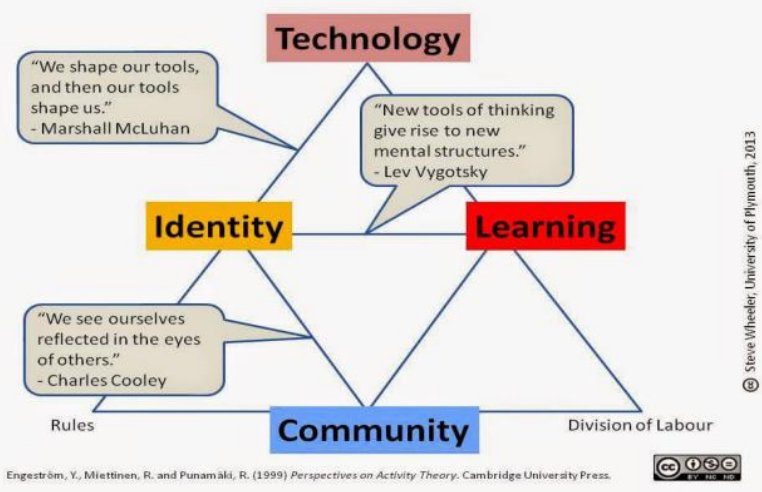

Figure 1. Combination of Technology and Society in getting Information

\section{RESULTS AND FINDINGS}

In the discussion of the Synergy of Regional Spatial Planning, theory is as an instrument in building a framework of thinking to see and understand research problems to get the results. Theories and concepts used are System Theory, Synergy Theory, Coordination Theory, Spatial Theory, Disaster Risk and Defense Territory Theory, International Humanitarian Law and the Universe Defense System to analyze the Synergy of Regional Spatial Planning 016 / BS and Bandung City Spatial Planning.

The Main Theory is the Lasker Synergy Theory with its aspects namely aspects of objectives, individual and organizational aspects, collaborative aspects or a combination of Human Resources and Material Resources, and supported by coordination aspects and other relevant theories that have been included in the fourth discussion aspects above.

In the discussion of objective Aspects, it is in accordance with the Guidelines for the Arrangement of Land Defense Spatial Planning for TA.2013. The regional Spatial Planning aims to realize the Land Defense Area as a forum for fostering defense capabilities; realizing Sishanta through Geography, Demography and Social Conditions aspects as forming supporting forces through reserve components and supporting components; Realizing the harmony of the Land Defense Area with other regions; Ensuring legal certainty about the existence of the Land Defense Area. Furthermore, according to the City Spatial Planning of Bandung in 2011 to 2030, the purpose of Bandung City spatial planning is to realize safe, comfortable, productive, effective, efficient, sustainable and environmentally sound, spatial-based, trade-based urban services and creative industries, national level based on the insights of Nusantara and National Resilience.

Based on the results of the interview about the research aspects of the objectives, some information was obtained: The Purpose of Spatial Planning for the Land Defense and Spatial Planning of the City Region has identical objectives to realize a safe spatial plan and the difference is in the time allocation. Spatial Planning

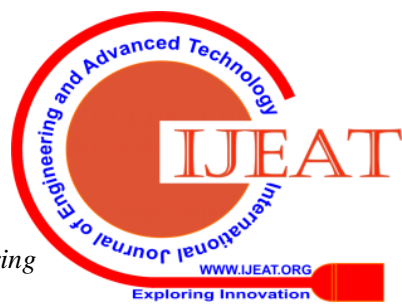


for the Land of Defense The Kodim was designated during the war. The Spatial Planning of the City of Bandung was destined for a period of peace. The Spatial Layout of the Kodim with the City Spatial Planning of Bandung City has a close relationship and both are complementary in terms of spatial planning, because they are in one administrative area. The Spatial Layout Area of the City Regional Kodim and Spatial Planning has a correlation in its principle namely the principle of integration, the principle of harmony, the principle of legal certainty, the principle of sustainability, the principle of protection of rights for the community. From the existing principle, the principle of legal certainty is the main foundation of the Regional Spatial Planning. Spatial Planning for the Land Defense Area of the Kodim does not yet have a legal umbrella. Without a legal umbrella, the Kodim Land Defense Area Spatial Planning is not optimal in synergizing with City Spatial Layouts that have Legal Legality.

In the discussion of Individual and Organizational Aspects, individuals are officials in each agency who have rank, position and competency levels in charge of Spatial Planning. At the Bappeda Office, there is the Head of Spatial Planning, Facilities and Infrastructure. At the Spatial Planning Office and Copyright there is the Head of Spatial Planning Division. At the Kodim, there were Operational Section Officers and Territorial Section Officers who were also in charge of the Land Defense Spatial Planning at the Kodim. Meanwhile, the organization is a part of the agency that becomes a container in carrying out the function of space.

The results of interviews about the research aspects of individuals and organizations, obtained information that: On the Individual Aspects synergy is still not done optimally, because officials at Bappeda and Distarcip in the field of spatial planning still do not know about how the Kodim Land Defense Area Spatial concept in its preparation, while in terms of organizational aspects, synergy efforts have been carried out limited to supporting the Bandung City Spatial Planning at the Focus Discuss Group (FGD) event held by the Bandung City Planning Agency.

Based on these real conditions, the Synergy of Spatial Planning of the Territorial Defense of the Kodim with City Spatial Layout in the Individual aspect is not optimal, while the aspects of the Urban Spatial Organizations with the principle of openness require communication with stakeholders both internally and externally. As for the Kodim's Land Defense Area Spatial Planning, its nature is only internal communication in its own environment, so that the organizational aspect is also not optimal.

In the discussion of Collaboration with a Combination of HR and Material Resources, the aspect of Human Resources are officials who are in the part of each agency (Bappeda, Distarcip, Kodim) who have competence in the field of Spatial Planning where they work together to carry out work processes to achieve the objectives of the institution, while Material Resources are all material which supports the production of agencies to be processed and produce spatial products of the City Defense Area Kodim and City Spatial Planning.

However, collaboration by combining aspects of Human Resources and Material Resources is still not optimal. This is because there is still no effective coordination in collaboration with $\mathrm{HR}$ in accordance with spatial competencies including in Material Resources in the form of data processed in producing Land Defense Area Spatial products. HR aspects need further dialogue and discussion to understand the Kodim Land Defense Area Spatial Planning as well as aspects of Material Resources in the form of spatial plan products. There has been no effective collaboration between Bappeda and Distarcip with Kodim 0618 / BS in the aspects of HR and Material Resources. The Bappeda and Distarcip parties hope that the Kodim 0618 / BS Land Defense Area Spatial Planning can collaborate with City Spatial Planning. Bappeda and Distarcip provide suggestions for collaborative efforts by combining HR and Material Resources by equating the perception and understanding between Land Defense Spatial Planning and City Spatial Planning through a technical, participatory and political approach.

Technology < Society, Government and TNI can be collaborated through the application of blended learning technology by focusing on technology knowledge, and how it can influence the community, government and TNI to study in the future. This section is similar, but it focuses a little more on the pros and cons of the learning process, and the main impacts they might have on education, and society in general. This part must be speculative, presented in the form of promotional talks, and hopefully makes it possible, and helps us to stop and eventually thinks in a better direction. The community and the TNI can cooperate through educational institutions in improving human resources to realize work programs in their respective fields.

In this study, Material Resources are the focus of the discussion because Material Resources in the form of Regional Spatial Products can be used to explain the synergy of spatial planning that considers disaster risk and the application of International Humanitarian Law in the framework of the readiness of the implementation of the Universal Defense System. The material resources in question are the Land Defense Area Spatial Map and the Bandung City Spatial Pattern Map. When these two map products are combined (overlay), then (See Fig. 2).

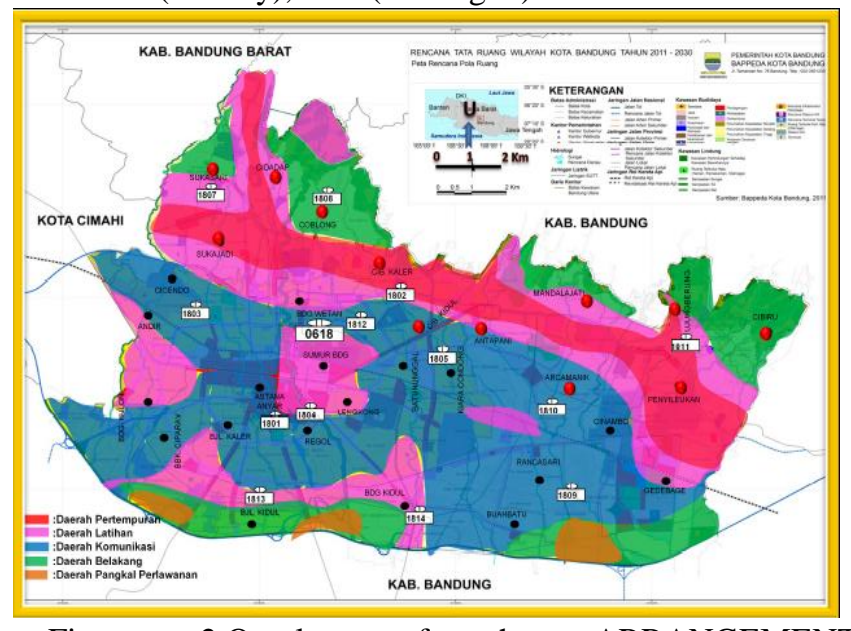

Figure 2.Overlay of the ARRANGEMENT REGISTRATION Map of the Military District Command 0618 / BS with a Map of the Spatial Planning Pattern of the City of Bandung

Published By:

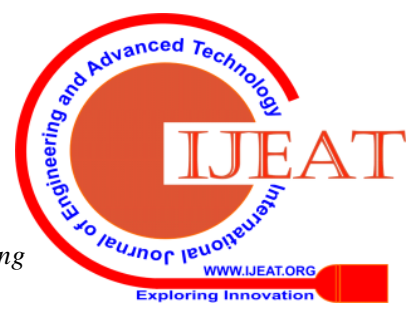


In the Land Defense Spatial Planning, the battle area has been determined to cover 12 Sub districts. This means that the 12 Sub districts (see figure 4.3) will be vulnerable to the danger of war. Twelve sub-districts prone to the dangers of war are Sukasari District, Cidadap District, Sukajadi District, Coblong District, Cibeunying Kaler District, Cibeunying Kidul District, Antapani District, Mandalajati District, Arcamanik District, Ujung Berung District, Cibiru District and Panyieulekan District.

The potential losses is caused by the dangers of war include, the number of people who are vulnerable to war hazards is 946,783 people, with details (Bandung Population Census 2012): Sukasari District (80,971 people), Cidadap District (57,999 people), Sukajadi District (107,133 people) ), Coblong District (130,023 people), Cibeunying Kaler District (70,111 people), Cibeunying Kidul District (106,571 people), Antapani District (73,608 people), Mandalajati District (62,849 people), Arcamanik District (68,519 people), Ujung Berung District ( 76,021 people), Cibiru District (71,191 people), and Panyieulekan District (39,787 people).

Then, facilities that are vulnerable to the danger of war based on the Bandung City Infrastructure and Spatial Data and Information Book, 2011 are as follows: Health Facilities: 4 units Hospital, 18 units Maternity Hospital, 28 Health Centers, Posyandu 184 units, Balai Treatment of 30 units. Educational facilities, from Elementary Schools to Senior High Schools totaling 323 units, with details of 157 TK units, 52 elementary units, 52 junior high schools, 40 high school units and 22 SMK units. Worship facilities 1647 units, with details: 852 Mosque units, 635 Langgar units, 127 Mushola units, 32 Church units, 1 Temple Unit. (See Appendix 3, Health and Education Facilities and Religion per District)

Furthermore, vital Objects that are vulnerable to the danger of war are based on Territorial Data of Kodim 0618 / BS, including the WTP (Water Treatment Plan) of PDAMs, East Bandung Electric Power Station, Pertamina Depot. Others who are vulnerable to the dangers of war are infrastructure in the form of roads and bridges, residential areas, traditional markets, modern markets, and government offices. Ploting battle areas in 12 sub-districts included in 4 Sub-Cities (SWK) in the North Bandung sector, namely SWK Bojonegara, SWK Cibeunying, SWK Karees, SWK Ujung Berung.

The Head of Bappeda's Spatial Planning and Infrastructure Planning said that if there is a war hitting the city of Bandung considering the city of Bandung was densely populated, this incident is a major disaster or the city of Bandung had higher disaster vulnerability. Because of the high population and the condition of the dense buildings, it is difficult to evacuate Bandung residents, and had an impact on increasing the number of victims. However, there is still no preparation for disaster evacuation spaces in the city of Bandung until now, thus the level of vulnerability of hazards increases.

The Head of the Spatial and Environmental Sub-Division of Bappeda of Bandung City stated that if a war occurs it can be categorized as a disaster meaning open war can cause damage and casualties. So as to save people's lives, the building fund area is a very important consideration.

Bandung Planning and Spatial Planning Staff stated that the level of vulnerability to disasters in the city of Bandung is high both natural disasters and war disasters. If there is a war, because of the high population, the risk of casualties is high.

The Distarcip Spatial Planning for the City of Bandung states that if there is a war disaster, because the number of residents with high conditions of dense buildings, it will complicate for evacuation of victims. The evacuation room in the city of Bandung has not yet been provided which endangers the population in a war.

Likewise, the Head of the Distarcip City Infrastructure Engineering Section of the City of Bandung stated that vulnerability of disasters for the city of Bandung tends to high. The dense population and limited land make the lack of open space which causes the power to respond to disasters to be low.

The statements above are a positive response to disaster risk from spatial stakeholders. Placement of Combat Areas in densely populated areas in the city of Bandung should be considered in the preparation of Kodim Land Defense Area Spatial products.

The Commander of the Military District Command 0618 / BS states that if there is a war in the City of Bandung, it is not sufficient as a fortress. In an air strike, the air resistance force is very limited, so that the city of Bandung has a high vulnerability in a war. Similar statement is stated by Chief of Staff Kodim 0618 / BS. This implies that there was a response and concern arising from the large population of residents from the Kodim when the densely populated area in the city of Bandung became a battleground.

The ability or capacity of the community to cope with the dangers of war in the area of the battle has not yet been built as seen from the enactment of the Land Defense Area Spatial Planning which has not been socialized to the Regional Government and the community as spatial stakeholders according to the UURI number 262007 article 60 concerning rights, obligations and participation of the community.

Based on the description above, the placement of battle areas that have been set in the Land Defense Spatial Plan has a high risk value if there is a war. Sudibyakto, in a multi-disaster risk paper, in his book questions "Disaster Management in Indonesia?". He contends that the disaster risk reduction target is the where the victim must be minimal or no victim. To minimize the victims of disasters during war in the city of Bandung, then in the preparation of the Kodim Land Defense Spatial Planning it is necessary to consider the risk of a war disaster. At present, the spatial stakeholders (Government and Community) of the City of Bandung do not yet know the Land Defense Area Spatial Planning, because it has not been socialized and the confidential nature of the Land Defense Territory.

From the statement above, it can be concluded that spatial stakeholders state that Bandung City has a high vulnerability to war disasters. The high vulnerability of war disasters is associated with International Humanitarian Law, concerning the protection of civilians and certain buildings in accordance with the Geneva Conventions.

The Head of Bappeda's Spatial Planning and Infrastructure Planning said that spatial planning of land defense areas in the city of Bandung must be

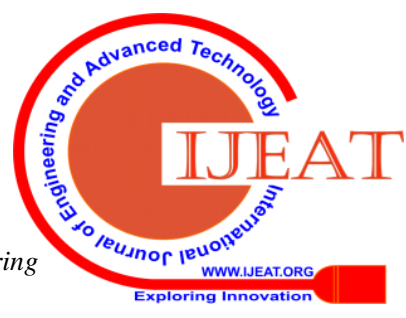


able to protect civilians and certain buildings protected in accordance with the Geneva Convention that is by applying International Humanitarian Law applied in the city Bandung. The government as the State organizer is obliged to seek its application in line with the mandate of Law No. 26 of 2007 concerning Spatial Planning to create a safe, comfortable, productive and sustainable National Territory space based on Archipelagic Insights and National Resilience.

Distarcip Spatial Planning of Bandung City states that Spatial planning in Bandung city must be able to protect civilians and certain buildings according to Republic of Indonesia Law No. 26 of 2007.

Based on the two statements above, it means that there is a response in the form of an expectation of the state's obligation to protect its people by applying International Humanitarian Law in the preparation of Land Defense Area Spatial products in the city of Bandung.

To reduce the high risk if there is a war, it is necessary to attempt to synergize the Spatial Layout of the Land of Defense with the Regional Spatial Planning of the City of Bandung. This is because synergy is the opening door so that the Land Defense Spatial Layout is in accordance with the consequences of the name that is carried as a spatial product which requires openness in accordance with the Spatial Layout principle.

City Spatial Layout with the Principle of Openness states that spatial planning is carried out by providing the widest possible access to the public to obtain information relating to spatial planning. With this principle, from the preparation of the City Spatial Plan to becoming a City Spatial Product all stakeholders are involved.

The principle of the Protection of the Land Defense Rights of the Kodim Land Area can be interpreted synonymous with the Principle of City Spatial Openness. Kodim's Land Defense Spatial Layout with the Principle of Rights Protection in the Declaration of the Land Defense Spatial Guidebook, it is stated that every Land Defense Area Spatial Activity is carried out while protecting the rights of the People's Rights. The People's Rights as stated in Article 30 paragraph 1 of the 1945 Constitution state that each citizen has the right and obligation to participate in the country's defense and security efforts. Article 30 paragraph 1 expressly states that the People (WNI) have the right and obligation to carry out state defense activities. Article 30 paragraph 2 of the 1945 Constitution states that state defense and security efforts are carried out through the Universal People's Defense and Security System (Sishankamrata) by the TNI and Polri as the Main Power, and the People as Supporting Strengths. Associated with this article, the principle of the Protection of the Spatial Rights of the Kodim Land Defense Region must also protect the rights of the people in an effort to defend the country. The People as a Supporting Power in Sishankamrata is the force involved. As a force involved in Sishankamrata, the people as spatial stakeholders are entitled to information about spatial planning including the Kodim Land Defense Area of Spatial Planning.

Therefore, the community knows and participates in the City Spatial Planning and City Spatial Layout, and the community in the area has increased capacity and it can reduce the level of risk in a disaster.
The results of the study on the scientific review the Kodim Land Area Regional Spatial Planning products with City Spatial Planning when compared with the approach method and the principle used. In Discussion of Coordination Aspects, state: Management; Educational Theory, Practice and Research, stating that coordination is a system and interaction process to realize the integration, harmony and simplicity of various inter and institutions in society through communication and dialogue between various individuals using management information systems and information technology.

In the aspect of coordination, information was obtained that the coordination between the Kodim and the Regional Government (Bappeda and Distarcip) had run well in the preparation of City Spatial Planning and other collaborations in the context of realizing security other than war; not in the context of spatial planning in facing war. What is hoped by Bappeda and Distarcip that is to equalize the perception and understanding of Land Defense Area of Spatial Plan for internal coordination between Bappeda and Distarcip according to the level of function is already established, but for coordination with the Kodim the party is still limited to general discussions to support the Bandung City Spatial Planning. For the preparation of the Kodim's Land Defense Area Spatial Planning, coordination has not yet been carried out, because the Kodim's Land Defense Area Spatial Planning is still confidential. The expectations of Bappeda and Distarcip, in compiling the Spatial Planning for the Land of Defense, the Military District Command needs to pay attention to City Spatial Layout, socialization to the public and study of peacetime spatial systems during war. On the Aspect of Coordination the Synergy of REGIONAL SPATIALS and City Spatial Planning, it has been carried out, yet still not optimal.

\section{Conclusion}

Implementation of the Land Defense Region Arrangement Policy is reviewed based on the Lasker Synergy Theory with its aspects namely aspects of the objectives, individual and organizational aspects, collaborative aspects or a combination of Human Resources and Material Resources, and supported by coordination aspects.

In Objective Aspects, the Purpose of Spatial Planning for the Land Defense and Spatial Planning of the City Region has an identical goal to realize a safe spatial plan. But, the difference is in terms of its time allocation. Spatial Planning for the Land of Defense The Kodim was designated during the war. The Spatial Planning of the City of Bandung was destined for a period of peace. However, Regional Spatial Synergy in the aspect of objectives is not optimal.

In terms of individual and organizational aspects, both the Individual and organizational aspects of the implementation of land defense arrangements have not been optimal, because individually and organizations of Bappeda and Distarcip did not know about the process of drafting and producing the Kodim Land Defense Area Plan.

Besides, collaboration by combining aspects of Human Resources and Material Resources between Bappeda / Distarcip and Kodim 0618 / 
BS is still not optimal. This is because there is no collaboration of HR in accordance with spatial competencies including in Material Resources in the form of processed data in producing RWP Kodim products.

In coordination aspect, the synergy is not optimal because coordination only supports City Spatial Layout preparation, but to support the Kodim RWP preparation, coordination is not carried out due to the secret nature of the RWP Kodim.

The inhibiting factor for the implementation of the defense area management policy is the lack of implementation of spatial education for the Kodim HR who handles the field of defense area planning, and the unfinished elaboration of the T.A. 2016

The supporting factor for the implementation of the defense area planning policy was the regular discussion forum about the preparation of the Regional Spatial Plan organized by the Bandung City Government

Furthermore, synergistic efforts to implement the land defense area arrangement policy are carried out by: 1) Improving the quality of Bappeda, Distarcip and Kodim HR education; 2) The Bandung City Government always holds regular meeting activities in a forum discussion group forum on the preparation of Regional Spatial plans.

\section{ACKNOWLEDGMENT}

The researchers address their greatest gratitude to West Java Provincial Government.

[1] REFERENCES

[2] BASIAGO, A. D. (1999). Economic, social, and environmental sustainability in development theory and urban planning practice. 16 .

[3] Belletti, G., Marescotti, A., \& Touzard, J.-M. (2017). Geographical Indications, Public Goods, and Sustainable Development: The Roles of Actors' Strategies and Public Policies. World Development, 98, 45-57. doi:10.1016/j.worlddev.2015.05.004

[4] Chatfield, A. T., \& Reddick, C. G. (2019). A framework for Internet of Things-enabled smart government: A case of IoT cybersecurity policies and use cases in U.S. federal government. Government Information Quarterly, $\quad 36(2), \quad 346-357$. doi:10.1016/j.giq.2018.09.007

[5] Dutta, K. (2018). Solving wicked problems: Searching for the critical cognitive trait. The International Journal of Management Education, 16(3), 493-503. doi:10.1016/j.ijme.2018.09.002

[6] Fuad, A. B. B. (2014). Political Identity and Election in Indonesian Democracy: A Case Study in Karang Pandan Village - Malang, Indonesia. Procedia Environmental Sciences, 20, 477-485. doi:10.1016/j.proenv.2014.03.060

[7] Gharehgozli, A. H., Mileski, J., Adams, A., \& von Zharen, W. (2017). Evaluating a "wicked problem": A conceptual framework on seaport resiliency in the event of weather disruptions. Technological Forecasting and Social Change, 121, 65-75. doi:10.1016/j.techfore.2016.11.006

[8] Gregory, A. (2019). UK Government Communication: The Cameron years and their ongoing legacy. Public Relations Review, 45(2), 202-216. doi:10.1016/j.pubrev.2018.08.003

[9] Hasan, Q. M. (2019). The power of constitution for enacting energy law and managing natural resources: The case of the Kurdistan Regional Government's oil contracts. Energy Policy, 128, 744-751. doi:10.1016/j.enpol.2019.01.012

[10] Hausken, K. (2010). Defense and attack of complex and dependent systems. Reliability Engineering \& System Safety, 95(1), 29-42. doi:10.1016/j.ress.2009.07.006

[11] INDONESIA, D. M. O. T. R. O. (2015). Indonesian Defence White Paper 2015. 150.

[12] INDONESIA, P. R. (2007). UNDANG-UNDANG REPUBLIK INDONESIA NOMOR 26 TAHUN 2007.

[13] Kivimaa, P., Hildén, M., Huitema, D., Jordan, A., \& Newig, J. (2017). Experiments in climate governance - A systematic review of research on energy and built environment transitions. Journal of Cleaner Production, 169, 17-29. doi:10.1016/j.jclepro.2017.01.027
[14] LAN, N. I. o. P. A. (2017). Wawasan Kebangsaan dan Nilai Nilai Bela Negara. 78.

[15] Lindgren, I., Madsen, C. Ø., Hofmann, S., \& Melin, U. (2019). Close encounters of the digital kind: A research agenda for the digitalization of public services. Government Information Quarterly. doi:10.1016/j.giq.2019.03.002

[16] MENHAN, M. P. R. I. (2013). PERATURAN MENTERI PERTAHANAN REPUBLIK INDONESIA NOMOR 19 TAHUN 2013 TENTANG RENCANA STRATEGIS PERTAHANAN NEGARA TAHUN 2010-2014 184.

[17] Merad, M., \& Trump, B. D. (2018). The legitimacy principle within French risk public policy: A reflective contribution to policy analytics. Sci Total Environ, 645, 1309-1322. doi:10.1016/j.scitotenv.2018.07.144

[18] PRESIDEN REPUBLIK INDONESIA. (2002). UNDANG-UNDANG REPUBLIK INDONESIA NOMOR 3 TAHUN 2002. 12.

[19] River, J., Currie, J., Crawford, T., Betihavas, V., \& Randall, S. (2016). A systematic review examining the effectiveness of blending technology with team-based learning. Nurse Educ Today, 45, 185-192. doi:10.1016/j.nedt.2016.08.012

[20] Sutriadi, R., \& Wulandari, A. (2014). Towards a Communicative City: Enhancing Urban Planning Coordination by the Support of Information and Communication Technology. Case Study Bandung Metropolitan Area, Indonesia. Procedia - Social and Behavioral Sciences, 135, 76-81. doi:10.1016/j.sbspro.2014.07.328

[21] Tarigan, A. K. M., Sagala, S., Samsura, D. A. A., Fiisabiilillah, D. F., Simarmata, H. A., \& Nababan, M. (2016). Bandung City, Indonesia. Cities, 50, 100-110. doi:10.1016/j.cities.2015.09.005

[22] Tuballa, M. L., \& Abundo, M. L. (2016). A review of the development of Smart Grid technologies. Renewable and Sustainable Energy Reviews, 59, 710-725. doi:10.1016/j.rser.2016.01.011

[23] Wicaksono Sarosa, W. M. a. B. H. R. (2012). Bandung Indonesia. 30. 